\title{
Pengenalan Benda-benda Bersejarah Museum Fatahillah Melalui Media Animasi Interaktif Untuk Anak Sekolah Dasar
}

\author{
Ummi Ulfah $^{1}$, Syarif Hidayatulloh ${ }^{2}$ \\ ${ }^{1}$ STMIK Nusa Mandiri \\ e-mail: ulfahghozali@gmail.com \\ ${ }^{2}$ STMIK Nusa Mandiri \\ e-mail: arrh56@gmail.com
}

\begin{abstract}
Interactive animation is a learning media that is quite interesting for children. This is because learning how to use animation is not difficult and more enjoyable for preschoolers than learning to use picture books or printed encyclopedias. This interactive animation was created to introduce the Fatahillah museum objects to preschoolers. This animation was made to provide knowledge for preschoolers about objects in the Fatahillah museum. Besides that, it can also be a more interesting and new learning method for preschoolers. In developing existing material, in this study three methods of data collection techniques will be used including observation, interviews and literature. Then for the system development model, it has been tested using software requirements analysis, design, coding, testing, and support. In this study also used some software to build interactive animations that will be created including Adobe Flash CS 3 and Adobe Photoshop CS 6. The results of the analysis show that the introduction process through interactive animation media has a big influence on improving preschoolers' understanding of introductory material the Fatahillah museum objects, this is because children's understanding will be better with explanations that use images, sound effects, and visuals.
\end{abstract}

Keywords: interactive animation, multimedia, museum Fatahillah

\section{PENDAHULUAN}

Pengenalan terhadap benda-benda sejarah pada anak sekolah dasar dirasa masi cukup minim. Metode pengenalan dan pembelajaran di sekolah-sekolah dasar sebagian besar masih menggunakan buku cetak. Banyak anak-anak seperti tidak tertarik dan terkesan cepat bosan dengan metode pembelajaran yang ada saat ini. Dengan kemajuan teknologi saat ini, tentu segala sesuatu seharusnya bisa dipermudah tidak terkecuali dalam dunia pendidikan. Dirasa sangat penting dilakukan penyesuaian terhadap metode pembelajaran dengan memanfaatkan teknologi yang sedang berkembang dan tentunya akan mendukung perkembangan anak-anak dalam mengenal benda-benda bersejarah. Salah satu upaya penyesuaian ialah dengan memberikan pendidikan bukan hanya dengan melalui buku-buku cetakan melainkan melalui sebuah media aplikasi komputer. Seiring dengan berkembangnya bahasa pemrograman, kini telah banyak metode-metode pengenalan berdasarkan prinsip audio visual yang diterapkan kedalam pengenalan.

Ditemukan adanya penyampaian informasi yang kurang menarik perhatian, seperti halnya cara pengemasan informasi, tampilan informasi bahkan media yang digunakan. Perkembangan teknologi komunikasi dan informasi atau Teknologi Informasi dan Komunikasi (TIK), telah memberikan pengaruh terhadap pembelajaran (Sari \& Triyono, 2013).

Animasi adalah usaha untuk membuat presentasi statis menjadi hidup. Animasi merupakan perubahan visual sepanjang waktu yang memberi kekuatan besar pada proyek multimedia dan halaman web yang dibuat. Banyak aplikasi multimedia yang menyediakan fasilitas animasi (Binanto, 2010).

Multimedia dapat digunakan dalam banyak bidang. Multimedia dapat masuk menjadi alat bantu yang menyenangkan. Beberapa bidang yang menggunakan multimedia adalah bisnis, sekolah, rumah, tempat umum, dan Virtual Reality (Binanto, 2010).

Masalah yang ada pada anak-anak sekolah dasar yaitu tidak bisa diajarkan hanya dengan melalui buku-buku cetak atau diajarkan dengan gambargambar cerakan dan dijelaskan dengan lisan. Tingkatan fokus anak-anak sekolah dasar masih jauh lebih rendah dari anak-anak yang sudah sekolah. Terkadang anak-anak sekolah dasar merasa jenuh pada saat mendengar penjelaskan oleh orangtua maupun guru-guru tempat-tempat pendidikan anakanak sekolah dasar, selain masalah pada anak-anak tersebut terkadang ada orang tua yang tidak terlalu pandai dalam menjelaska sebuah pengetahuan kepada anak-anaknya. Dalam hal ini museum adalah salah satu tempat yang memiliki banyak 
pengetahuan yang menarik bagi anak-anak sekolah dasar.

Pada umumnya, kesan pertama yang muncul dari sebuah museum adalah pasif dan monoton. Tidak jarang juga keberadaan museum menghadapi kendala klasik berupa biaya pemeliharaan yang tidak memadai untuk mempertahankan kelangsungan hidupnya. Museum memang memiliki nilai yang agung. Museum adalah wadah cerminan pertumbuhan peradaban umat manusia. Berperan sebagai sumber inspirasi dan sebagai suaka alam dan budaya serta pusat dokumentasi dan penelitian (Susanto \& Budiasa, 2012).

Rancang bangun aplikasi E-Museum ini merupakan sebuah inovasi baru yang bertujuan untuk membantu bahkan dapat menggantikan seorang pemandu dimuseum, karena mengingat terbatasnya jumlah tenaga kerja pemandu pada museum. aplikasi ini diharapkan dapat meningkatkan minat masyarakat khususnya para pelajar untuk berkunjung belajar mengenali sejarah (Kartikadarma, Rizqa, \& Trirosandi, 2010).

Penelitian ini mengangkat salah satu musem terkenal di Jakarta yaitu Fatahillah. Museum Fatahillah menyimpan berbagai macam benda-benda bersejarah dari masa penjajahan dahulu. Selain itu, museum Fatahillah juga sering menjadi tujuan study wisata oleh anak-anak sekolah dasar. Oleh karena itu penelitian ini bertujuan untuk membuat media pengenalan yang memanfaatkan teknologi yang ditujukan untuk anak-anak sekolah dasar dengan tujuan agar pengenalan atau pengenalan mengenai musium Fatahillah ini semakin optimal, sebagai salah satu upaya penyesuaian ialah dengan memberikan pengenalan melalui sebuah media pemrograman berbasis animasi interaktif.

\section{METODOLOGI PENELITIAN}

Ada 2 tahap metode penelitian yang dilakukan dalam penelitian ini yaitu:

1. Teknik Pengumpulan Data

a. Observasi

Pengamatan berfokus pada kondisi dan susasana serta mendata benda-benda koleksi museum Fatahillah dengan mengunjungi langsung ke museum Fatahillah di daerah Jakarta Kota.

b. Wawancara

Wawancara dilakukan kepada beberapa orang tuda dari murid-murid Sekolah Dasar secara acak dan pegawai museum Fatahillah

c. Studi Pustaka

Studi pustaka dilakukan dengan mencarai referensi melalui buku-buku encyclopedia di perpustakaan. Tidak hanya dengan melalui buku-buku, penelitian ini juga mendapatkan refrensi dari media internet dan artikel-artikel jurnal peneltiian.

2. Model Pengembangan sistem

Pada model pengembangan sistem dilakukan beberapa tahapan yang akan digunakan untuk mengembangkan sistem pengenalan yang sudah ada.

a. Analisa kebutuhan software

Dalam menganalisa kebutuhan software, penulis menganalisa apa saja yang dapat mendukung dalam pembuatan animasi interaktif pengenalan benda-benda koleksi museum Fatahillah ini, yaitu dengan menyesuaikan tingkat kesulitan aplikasi ini untuk penggunanya, dalam hal ini yaitu anakanak sekolah dasar. analisis kebutuhan software adalah proses pengumpulan kebutuhan dilakukan secara intensif untuk menspesifikasikan kebutuhan perangkat lunak agar dapat dipahami perangkat lunak seperti apa yang dibutuhkan oleh user (AS \& Salahuddin, 2014).

b. Perancangan

Pada tahap desain dituangkan terlebih dahulu melalui sebuah konsep yang dapat disebut juga dangan Storyboard, setelah itu dimulailah perancangan animasi pengenalan tentang museum dengan menggunakan Software Adobe Flash CS3. Adapun tampilan antar muka pengguna animasi interaktif ini tedapat beberapa tombol pada menu yang saling terhubung sesuai dengan fungsi dari tombol-tombol tersebut. Dengan fungsifungsi yang terdapat didalam tombol pada animasi pengenalan tentang museum ini maka pengguna akan cepat mengerti cara penggunaan animasi interaktif ini.

c. Code Generations

Bahasa pemrograman yang di pakai untuk pembuatan animasi interaktif pengenalan tentang museum ini adalah Action Script 2.0 yang terdapat didalam beberapa Software animasi yang di antaranya adalah Adobe Flas. Bahasa pemrograman yang digunakan oleh penulis untuk membuat animasi interaktif ini adalah Adobe Flash CS3. Animasi interaktif yang penulis buat termasuk dalam bahasa pemprograman berorientasi objek.

d. Pengujian

Animasi interaktif pengenalan tentang museum ini diuji dengan 2 tahap pengujian, yang pertama melalui metode pengujian White Box di mana tahap pengujian ini meliputi pengujian algoritma atau logika dari program yang dibuat. Pengujian White Box adalah metode desain Test Case yang menggunakan struktur kontrol desain procedural untuk memperoleh Test Case (Ladjamudin, 2006).

Kemudian pengujian yang kedua adalah melalui pengujian Black Box yaitu pengujian masukan atau Input apakah masukan tersebut mendapatkan hasil yang sesuai diharapkan atau tidak, seperti contoh ketika pengguna mengklik sebuah tombol maka tombol tersebut akan terhubung dan membuka sebuah tampilan yang sesuai dengan fungsi 
dari tombol yang diklik oleh pengguna tersebut. Black box testing adalah tipe testing yang memperlakukan perangkat lunak yang tidak diketahui kinerja internalnya. Sehingga para tester memandang perangkat lunak seperti layaknya sebuah kotak hitam yang tidak penting dilihat isinya, tidak cukup dikenai proses testing di bagian luar (Rizky, 2011).

e. Support

Animasi interaktif pengenalan tentang museum ini dirancang dan dibuat dengan menggunakan Software Adobe Flash CS3 dengan sistem operasi Windows 7 Ultimate. Dan di dukung dengan Hardware berupa prosesor Intel pentium B960, Memory 4 GB DDR3 dengan Hardisk 500GB.

\section{HASIL DAN PEMBAHASAN}

1. Analisa Kebutuhan

Analisa kebutuhan software maupun hardware merupakan langkah awal untuk menentukan apa yang dibutuhkan dalam pembuatan animasi interaktif pengenalan benda-benda koleksi museum Fatahillah. Analisa kebutuhan merupakan analisis terhadap semua kebutuhan yang diperlukan perangkat lunak yang akan dikembangkan dan perangkan keras sebagai pendukungnya. Analisis kebutuhan perangkat lunak mencakup analisis terhadap kebutuhan fungsional dan non-fungsional. Analisis kebutuhan yang dilakukan terhadap perangkat lunak akan menghasilkan spesifikasi kebutuhan perangkat lunak tersebut.

a. Identifikasi dan Analisa Kebutuhan Pemakai Aplikasi animasi interaktif pengenalan bendabenda koleksi museum Fatahillah ini ditujukan untuk anak-anak sekolah dasar. Aplikasi yang dirancang agar dapat menjadi salah satu alternatif metode pengenalan museum Fatahillah yang diharapkan dapat membantu anak-anak sekolah dasar untuk mengenal benda-benda koleksi museum dengan lebih menarik dan menyenangkan.

Pembuatan aplikasi ini bertujuan untuk memberikan metode pengenalan yang berbeda dalam hal mengenal benda-benda bersejarah dalam museum Fatahillah. Aplikasi animasi interaktif ini tidak hanya bersifat mendidik tetapi juga menghibur. Aplikasi ini dibuat dengan objek-objek dan animasi yang menarik sehingga siswa dapat memahami materi dengan lebih mudah dimengerti.

b. Analisa Kebutuhan Sistem

1) Spesifikasi Perangkat Lunak

Perangkat lunak atau software yang penulis gunakan dalam perancangan animasi interaktif pengenalan benda-benda koleksi museum Fatahillah diantaranya Adobe
Flash, Adobe Photoshop, dan Audacity untuk merekan suara.

2) Spesifikasi Perangkat Keras

Perangkat keras adalah seperangkat alat yang dapat membantu kinerja sistem operasi, yang merupakan bagian vital dalam perangkat lunak. Berikut adalah spesifikasi perangkat keras yang digunakan dalam perancangan animasi interaktif pengenalan benda-benda bersejarah museum Fatahillah.

Tabel 1. Spesifikasi perangkat keras untuk perancangan

\begin{tabular}{lc}
\hline \multicolumn{1}{c}{ Komponen } & Spesifikasi \\
\hline Processor & Pentium Core i3 $2.53 \mathrm{GHz}$ \\
Memory & $4 \mathrm{~GB}$ \\
VGA & $763 \mathrm{MB}$ \\
Harddisk & $500 \mathrm{~GB}$ \\
\hline Sumber : Hasil penelitian &
\end{tabular}

Sementara kebutuhan minimum hardware untuk menjalankan animasi interaktif pembelajaran benda-benda sejarah, yaitu:

Tabel 2. Spesifikasi minimum untuk perangkat

\begin{tabular}{lc}
\multicolumn{2}{c}{ keras } \\
\hline Komponen & Spesifikasi \\
\hline Processor & Celeron D 3.0GHz \\
Memory & $512 \mathrm{MB}$ \\
VGA & $40 \mathrm{MB}$ \\
Harddisk & $500 \mathrm{~GB}$ \\
Monitor & 14"SVGA \\
Speaker Active & Standard \\
\hline Sumber : Hasil penelitian &
\end{tabular}

\section{Perancangan}

Tahap perancangan atau desain ini bertujuan untuk memenuhi kebutuhan pengguna dan memberikan suatu gambaran mengenai aplikasi yang akan dibuat.

a. Karakteristik Software

1) Format

Format yang digunakan untuk aplikasi ini adalah format berekstensi *.exe, sehingga pengguna dapat menjalankan aplikasi ini di semua komputer dengan platform Microsoft Windows. Dalam animasi interaktif pengenalan benda-benda koleksi museum Fatahillah ini terdapat menu BENDA yang menjelaskan benda-benda koleksi, menu SEJARAH yang menjelaskan sejarah berdirinya museum, dan Pada menu BERMAIN akan diminta untuk menyatukan gambar sesuai ketentuan.

2) Rule

Pada animasi interaktif ini terdapat scene pembuka, menu utama, benda, permainan, 
sejarah, informasi, dan latihan soal. Pertama kali aplikasi ini dijalankan pengguna akan masuk ke menu pembuka, pengguna secara otomatis masuk ke menu utama. Pengguna harus terlebih dahulu mempelajari menu sejarah dan pengenalan benda-benda museum pada menu benda. Setelah itu pengguna dapat memilih menu bermain. Dalam menu bermain pengguna dapat bermain.

3) Policy

Dalam menu bermain, ketika pengguna dapat menyatukan gambar sesuai dengan ketentuan yang telah ditentukan, maka akan mendapatkan nilai 125 . Nilai ini akan bertambah sesuai dengan jumlah gambar yang harus disatukan, tetapi jika pengguna tidak sesuai dalam menyatukan gambar maka akan kembali ke posisi sebelum di pindahkan. Pengguna hanya dapat menyatukan gambar satu kali saja. Jika ingin mengulangi bermain kembali permainan pada animasi ini maka dapat klik tombol ulangi. Untuk menjalankan animasi interaktif ini pengguna harus mengeksekusi file yang berekstensi *.exe.

4) Scenario

Pengguna harus menjalankan aplikasi animasi pada ruang lingkup sistem operasi bebasis windows yang dapat menjalankan file yang berekstensi *.exe. Berikutnya pengguna dapat belajar dan bermain dengan sebuah permainan menyatukan gambar.

5) Roles

Pengguna harus menjawab 10 soal dengan cara mengklik salah satu jawaban yang menurut pengguna benar. Jika pengguna mampu menjawab soal dengan benar maka poin akan bertambah 10, Namun jika pengguna tidak mampu menjawab dengan benar maka poin tidak akna bertambah dan tetap dinyatakan 0 .

6) Event/Challenge

Tantangan yang terdapat dalam animasi interaktif pengenalan benda-benda koleksi museum Fatahillah ini tidak terlalu sulit, pengguna hanya perlu menyatukan gambar yang ada di sisi sebelah kiri pada animasi sebanyak 8 gambar yang di susun secara acak dan harus di sesuaikan dengan gambar yang telah ditentukan.

7) Decision

Pada menu pengenalan benda-benda museum koleksi Fatahillah pengguna dapat memilih tombol-tombol materi sesuai yang ingin dipelajari. Dan pada menu pengenalan benda-benda museum koleksi
Fatahillah pengguna bebas menentukan materi apa saja yang ingin dipelajari di mengerti.

8) Level

Animasi yang penulis buat tidak di klasifikasikan berdasarkan level atau tingkat kesulitan.

9) Score Model

Dalam animasi interaktif pengenalan benda-benda koleksi museum fatahillah ini, pada menu bermain jumlah nilai akan diakumulasi sesuai dengan banyaknya jumlah gambar yang disatukan ke terget gambar yang ada di sisi sebelah kanan pada animasi. Jika pengguna mampu menyatukan gambar akan mendapatkan skor 125.

10) Indicator

Indikator keberhasilan pada latihan adalah dengan menjawab setiap soal dengan benar sesuai dengan pertanyaan yang ada pada tampilan menu latihan.

11) Symbol

Dalam desain animasi interaktif pengenalan benda-benda museum fatahillah ini, penulis menggunakan simbol-simbol khusus yang dapat menarik perhatian pengguna. Simbol tersebut merupakan objek yang difungsikan sebagai tombol yang diberi perintah menggunakan script atau coding untuk melakukan sebuah eksekusi yang diinginkan sesuai jalannya program

b. Storyboard

1) Scene Pembuka

Gambaran dari storyboard scene pembuka dijelaskan pada tabel berikut:

Tabel 3. Storyboard scene pembuka

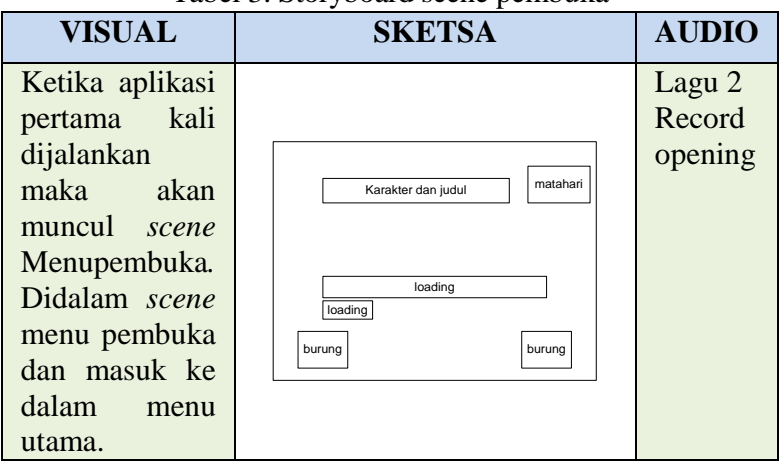

Sumber : Hasil penelitian

2) Storyboard Scene Menu Gambaran dari storuboard menu dijelaskan pada tabel berikut: 
Tabel 4. Storyboard Scene Menu

\begin{tabular}{|c|c|c|}
\hline VISUAL & SKETSA & AUDIO \\
\hline $\begin{array}{l}\text { Dalam scene menu } \\
\text { utama terdapat } \\
\text { gambar bergerak dan } \\
\text { beberapar tombol } \\
\text { menu seperti } \\
\text { tombolbenda, tombol } \\
\text { sejarah, tombol } \\
\text { permainan, tombol } \\
\text { latihan, jika salah } \\
\text { satu di klik maka } \\
\text { akan muncul menu } \\
\text { atau tampilan sesuai } \\
\text { dengan fungsi dari } \\
\text { masing-masing } \\
\text { tombol. Di dalam } \\
\text { tombol benda berisi } \\
\text { materi-materi } \\
\text { tentang pengenalan } \\
\text { benda-benda } \\
\text { museum fatahillah. } \\
\text { Kemudian pada } \\
\text { tombol permainan } \\
\text { terdapat permaianan } \\
\text { berupa menyamakan } \\
\text { gambar yg sudah di } \\
\text { sediakan di sebelah } \\
\text { kanan program, }\end{array}$ & 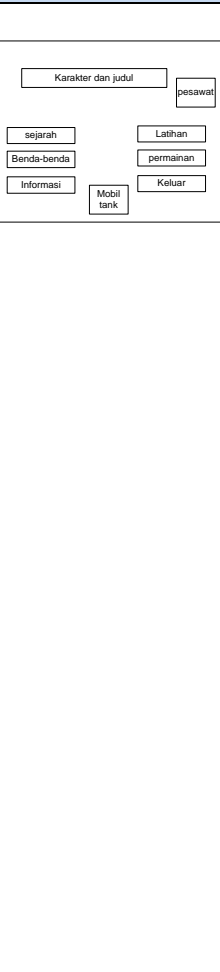 & $\begin{array}{l}\text { Acoustic2 } \\
\text { Efek } \\
\text { gelembung } \\
\text { air }\end{array}$ \\
\hline
\end{tabular}

Sumber : Hasil penelitian

\section{3) Storyboard Sejarah}

Gambaran dari storyboard sejarah dijelaskan pada tabel berikut:

Tabel 5. Storyboard scene Menu

\begin{tabular}{|c|c|c|c|c|}
\hline VISUAL & \multicolumn{3}{|c|}{ SKETSA } & AUDI \\
\hline $\begin{array}{l}\text { Pada tampilan menu } \\
\text { sejarah berisi materi } \\
\text { tentang penjelasan } \\
\text { dari berdiri nya } \\
\text { bangunan hingga } \\
\text { letak lokasi museum } \\
\text { berada. Pada scene } \\
\text { ini terdapat tombol } \\
\text { lanjut dan kembali, } \\
\text { yang apabila di klik } \\
\text { untuk membuka } \\
\text { halaman berikut nya } \\
\text { atau balik } \\
\text { halaman ke } \\
\text { sebelumnya, } \\
\text { kemudian terdapat } \\
\text { tombol menu utama } \\
\text { yang apabila di klik } \\
\text { maka akan kembali } \\
\text { kepada menu utama. }\end{array}$ & karakter & $\begin{array}{c}\text { judul } \\
\text { Isi mater }\end{array}$ & \begin{tabular}{|l}
$\begin{array}{l}\text { Tombol } \\
\text { keluar }\end{array}$ \\
$\begin{array}{l}\text { Tombol } \\
\text { lanjiut }\end{array}$
\end{tabular} & $\begin{array}{l}\text { Lagu } 3 \\
\text { Blip } \\
\text { Dink } \\
\text { Record } \\
\text { sejarah }\end{array}$ \\
\hline
\end{tabular}

\section{4) Storyboard Permainan}

Gambaran dari storyboard permainan dijelaskan pada tabel berikut:
Tabel 6. Storyboard tampilan permainan

\begin{tabular}{|c|c|c|}
\hline VISUAL & SKETSA & AUDIO \\
\hline $\begin{array}{lr}\text { Pada } & \text { tampilan } \\
\text { permainan terdapat } \\
\text { perintah memasukan } \\
\text { nama, dan kolom } \\
\text { untuk menginput } \\
\text { nama pengguna, } \\
\text { ketika pengguna } \\
\text { sudah menulis nama } \\
\text { ada tombol mulai } \\
\text { yang berfungsi } \\
\text { untuk memulai } \\
\text { permainan tersebut. } \\
\text { Dimana permainan } \\
\text { nya adalah } \\
\text { menyesuaikan } \\
\text { gambar yang ada di } \\
\text { sebelah kanan } \\
\text { program, } \\
\text { permainan di } \\
\text { pengguna ini } \\
\text { mendapatkan nilai } \\
\text { ketika gambar di } \\
\text { sesuaikan dengan } \\
\text { benar. Dan ketika } \\
\text { pengguna berhasil } \\
\text { menyesuaikan } \\
\text { gambar sampai } \\
\text { gambar terakhir } \\
\text { akan mendapatkan } \\
\text { nilai 100. }\end{array}$ & 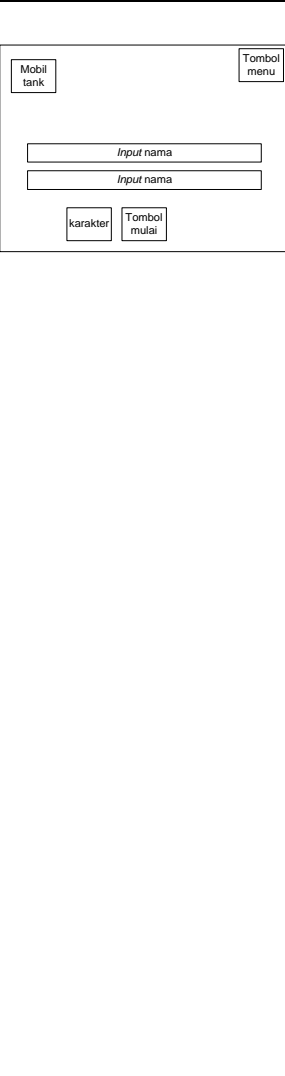 & $\begin{array}{l}\text { Acoustic } \\
2 \\
\text { Tepuk } 1 \\
\text { Lose } \\
\text { Blip } \\
\text { Dink }\end{array}$ \\
\hline
\end{tabular}

Sumber : Hasil penelitian

\section{5) Storyboard Benda}

Gambaran dari Storyboard benda dijelaskan pada tabel berikut ini:

Tabel 7. Storyboard tambpilan benda

\begin{tabular}{|c|c|c|c|}
\hline VISUAL & \multicolumn{2}{|c|}{ SKETSA } & AUDIO \\
\hline $\begin{array}{lr}\text { Pada } & \text { tampilan } \\
\text { benda terdapat } 2 \\
\text { menu tombol } \\
\text { lantai1 dan tombol } \\
\text { lantai 2. Jika pilih } \\
\text { tombol lantai1 } \\
\text { maka akan masuk } \\
\text { kedalam materi } \\
\text { pengenalan benda- } \\
\text { benda museum } \\
\text { fatahillah lantai1, } \\
\text { sedangkan jika } \\
\text { memilih lantai2 } \\
\text { maka akan masuk } \\
\text { kedalam materi } \\
\text { pengenalan gambar } \\
\text { benda-benda } \\
\text { museum fatahillah } \\
\text { lantai2. Jika pilih } \\
\text { tombol keluar maka } \\
\text { akan kembali ke } \\
\text { menu utama. }\end{array}$ & Lantai 1 & Lantai 2 & $\begin{array}{l}\text { Blip } \\
\text { Dink } \\
\text { Acoustic } \\
\text { Record } \\
\text { benda }\end{array}$ \\
\hline
\end{tabular}

Sumber : Hasil penelitian 
6) Storyboard Informasi

Gambaran dari storyboard informasi

dijelaskan pada tabel berikut:

Tabel 8. Storyboard tampilan informasi

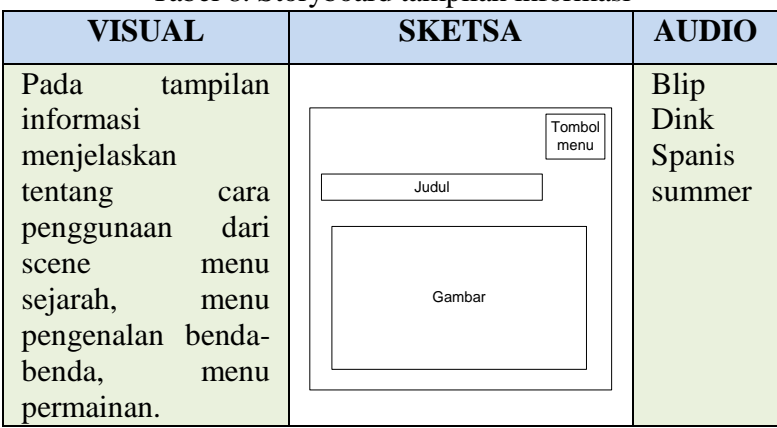

Sumber : Hasil penelitian

c. User Interface

1) Scene Pembuka

Pada scene pembuka dirancang dengan menampilkan banyak gambar serta gerakan yang cukup menarik, selain itu pada menu pembuka ini berada di sebuah halaman depan museum fatahillah dengan beberapa hiasan pohon serta burung yang berterbangan. dan pengguna dapat memulai animasi interaktif ini secara otomatis masuk kedalam menu utama.

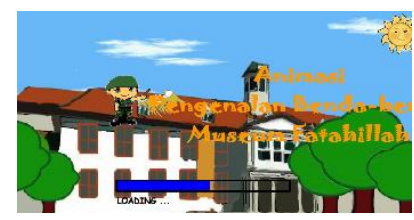

Sumber : Hasil penelitian

Gambar 1. Menu scene pembuka

2) Scene Menu Utama

Pada scene menu utama menggambarkan kamar yang dimana didalamnya terdapat berbagai menu diantaranya menu sejarah museum, menu pengenalan benda-benda museum, menu, permainan, menu latihan soal, menu informasi, menu keluar.

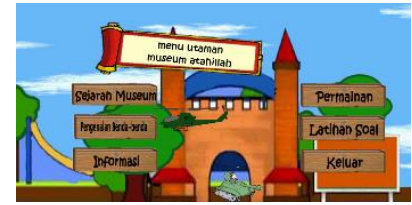

Sumber : Hasil penelitian

Gambar 2. Scene menu utama

3) Scene Benda

Pada scene benda terdapat 2 (dua) tombol yang cukup besar diantaranya lantai 1 dan lantai 2.

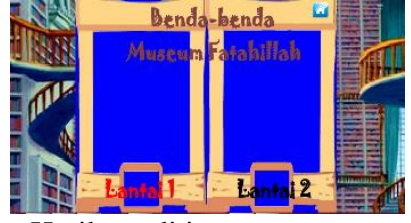

Sumber : Hasil penelitian

Gambar 4. Scene benda

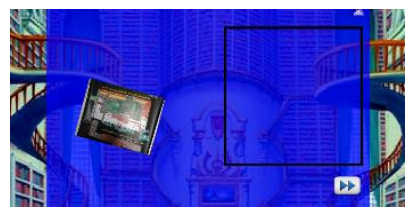

Sumber : Hasil penelitian

Gambar 5. Scene hasil benda

4) Scene Bermain

Pada scene bermain terdapat gambargambar yang harus di sesuaikan dengan objek yang ada di sebelah kanan. Jika pengguna berhasil memindahkan potongan gambar pada target, maka akan mendapatkan nilai 125 . Total keseluruhan nilai pada scene bermain ini adalah 1000 .

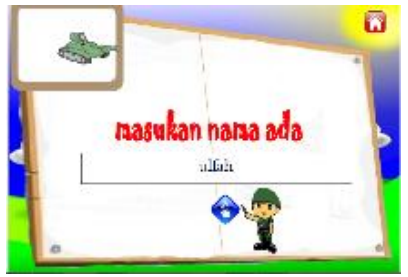

Sumber : Hasil penelitian

Gambar 6. Scene bermain

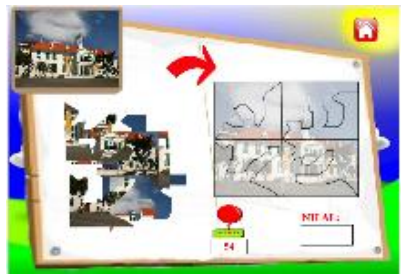

Sumber : Hasil penelitian

Gambar 7. Scene hasil bermain

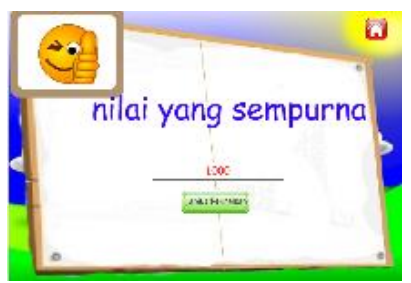

Sumber : Hasil penelitian

Gambar 8. Scene hasil bermain sempurna 


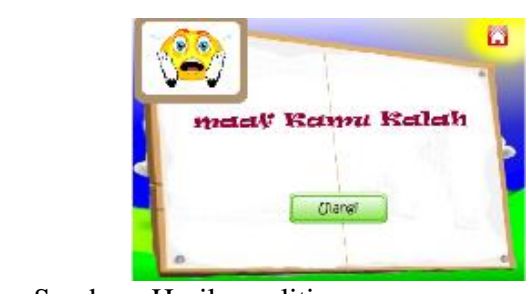

Sumber : Hasil penelitian

Gambar 9. Scene hasil bermain kalah

5) Scene Latihan

Scene latihan ini adalah kumpulan soalsoal pilihan ganda yang berfungsi untuk menguji ketangkasan dan pemahaman pengguna pada materi yang ada pada animasi interaktif pengenalan tentang museum ini.

\section{Gambar 10. Scene latihan}

Sumber : Hasil penelitian
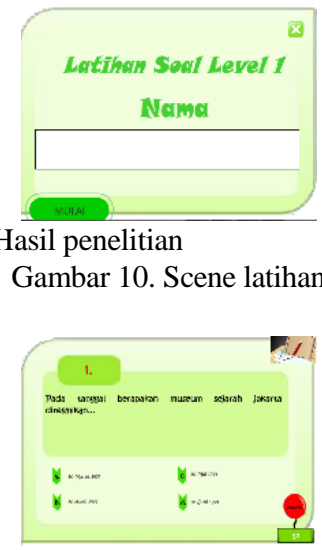

Sumber : Hasil penelitian

Gambar 11. Scene soal latihan

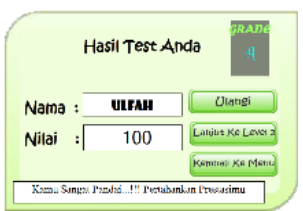

Sumber : Hasil penelitian

Gambar 12. Scene hasil latihan

6) Scene Informasi

Pada scene informasi terdapat contoh gambar tampilan setiap scene yang berfungsi sebagai tutorial atau informasi tentang penggunaan animasi interaktif media pengenalan benda-benda koleksi museum Fatahillah.

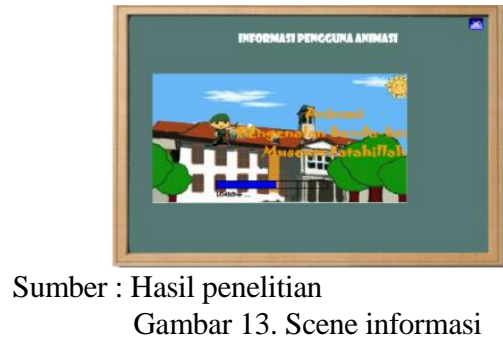

d. State Transition Diagram
State Transition Diagram (STD) adalah suatu modeling tool yang menggambarkan suatu sifat ketergantungan terhadap real time system, dan tampilan interface pada sistem aktif. State transition diagram juga berfungsi untuk menjelaskan alur-alur pada aplikasi animasi yang penulis rancang.

Berikut state transition diagram dari semua scene yang terdapat pada animasi interaktif pengenalan benda-benda koleksi museum Fatahillah:

a)Scene Menu Utama

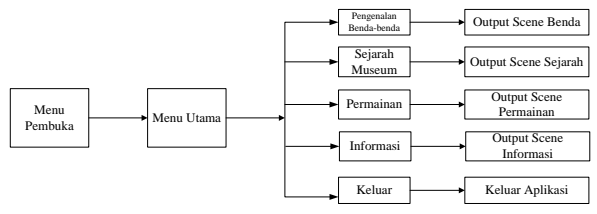

Sumber : Hasil penelitian

Gambar 14. State Transition Diagram menu utama

Diagram ini menggambarkan menu awal pada aplikasi yang dimana ketika pertama kali pengguna membuka dan menjalankan aplikasi animasi ini maka akan muncul tampilan pembuka dengan tampilan menarik dan terdapat sebuah tombol mulaiuntuk masuk ke dalam menu utama yang tentunya terdapat fitur-fitur.

b) Scene Benda

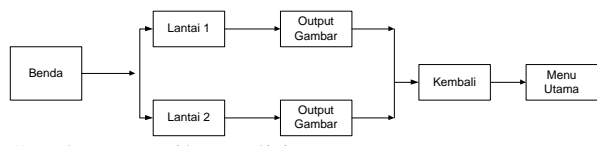

Sumber : Hasil penelitian

Gambar 15. State Transition Diagram benda

Pada scene Bermain terdapat gambar yang harus di sesuaikan oleh pengguna, dimana setiap gambar harus disamakan dengan objek yang ada di sebelah kiri. Setiap gambar yang sesuai akan mendapatkan nilai125.

c)Scene Bermain

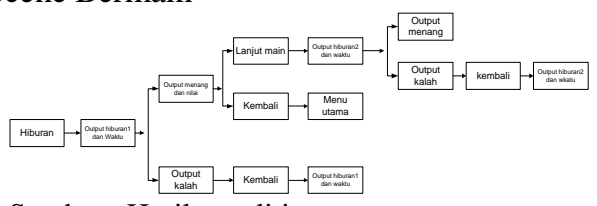

Sumber : Hasil penelitian

Gambar 16. State Transition Bermain

Pada scene Bermain terdapat gambar yang harus di sesuaikan oleh pengguna, dimana setiap gambar harus disamakan dengan objek yang ada di sebelah kiri. Setiap gambar yang sesuai akan mendapatkan nilai125. 
d) Scene Latihan

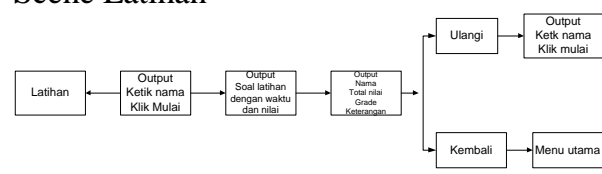

Sumber : Hasil penelitian

Gambar 17. State Transition Latihan

Pada Scene latihan ini adalah kumpulan soal-soal pilihan ganda yang berfungsi untuk menguji ketangkasan dan pemahaman pengguna pada materi yang ada pada animasi interaktif pengenalan tentang museum ini.

e)Scene Informasi

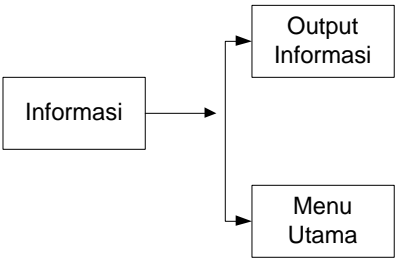

Sumber : Hasil penelitian

Gambar 11. State Transition Informasi

Pada scene Informasi terdapat gambar yang menjelaskan cara penggunaan aplikasi animasi ini. Di dalam animasi ini terdapat tombol keluar untuk kembali ke menu utama.

3. Code generation dari aplikasi animasi interaktif Pengenalan benda-benda museum fatahillah yang dibuat adalah sebagai berikut:

a. Scene Menu Utama

1) Tombol Benda on(release) \{stopAllsounds(); gotoAndPlay ("benda", 1);

2) Tombol Sejarah on (release) \{stopAllsounds(); gotoAndPlay ("sejarah",1);

3) Tombol Permainan on (release) \{stopAllsounds( ); gotoAndPlay ("permainan", 1);

4) Tombol Latihan on (release) \{stopAllsounds(); gotoAndPlay ("latihan",1);

5) Tombol Keluar on (release) \{fscommand("quit", true);

b. Scene Benda

1) Tombol Lantai 1 on (release) \{nextFrame ()$;\}$

2) Tombol Lantai 2 on (release) \{gotoAndPlay (12);

3) Tombol Home on (release) \{stopAllsounds(); gotoAndPlay ("menu", 1$)$; \}

4) Tombol Next on (release) \{nextFrame ();

5) Tombol Prev on (release) $\{$ nextFrame ()$;\}$

c. Scene Sejarah

1) Tombol Keluar on(release) \{stopAllSounds(); gotoAndPlay ("menu", 1); \}

2) Tombol Next on (release) \{nextFrame ()$;\}$

3) Tombol Prev on (release) \{nextFrame ()$;\}$

d. Scene Permainan

1) Tombol Keluar on (release) \{stopAllSounds (); gotoAndPlay ("menu", 1); $\}$

2) Tombol mulai on (release) \{nextFrame ();

3) Tombol menu utama on (release) \{stopAllSounds (); gotoAndPlay ("menu", 1);

4) Tombol Ulangi on (release) \{nextFrame();\}

5) Tombol Lanjut Permainan on (release) \{nextFrame ()$;\}$

e. Scene Latihan Soal

1) Tombol Keluar on (release) \{stopAllsounds(); gotoAndPlay ("menu", 1); \}

2) Tombol mulai on (release) \{nextFrame ();

3) Tombol Ulangi on (release) \{nextFrame ();

4) Tombol Lanjut ke level 2 on (release) \{nextFrame(); \}

5) Tombol Kembali Ke menu on (release) \{stopAllsounds(); gotoAndPlay ("menu", 1);

4. Pengujian

Pada tahap ini digunakan dua tahap pengujian yaitu white box testing dan black box testing dengan menampilkan hasil pengujian scene benda.

a. White Box Testing

Dibawah ini merupakan Flowchart dari Scene benda pada animasi interaktif pengenalan benda-benda museum Fatahillah:

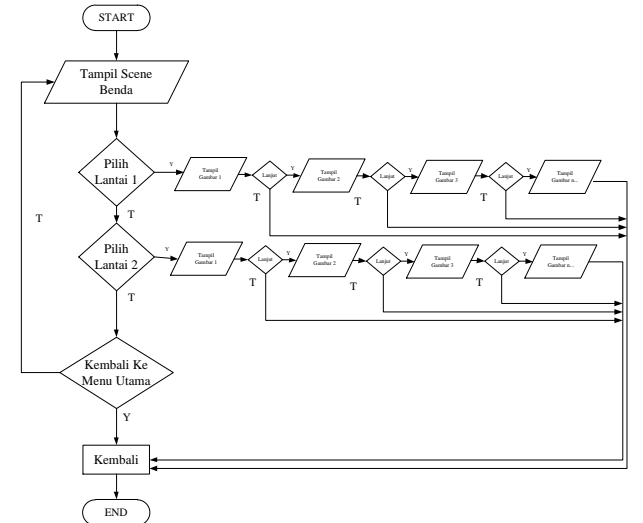

Sumber : Hasil penelitian

Gambar 12. Flowchart scene benda

Dibawah ini merupakan grafik alir dari Scene benda pada animasi interaktif pengenalan tentang benda-benda koleksi museum Fatahillah: 


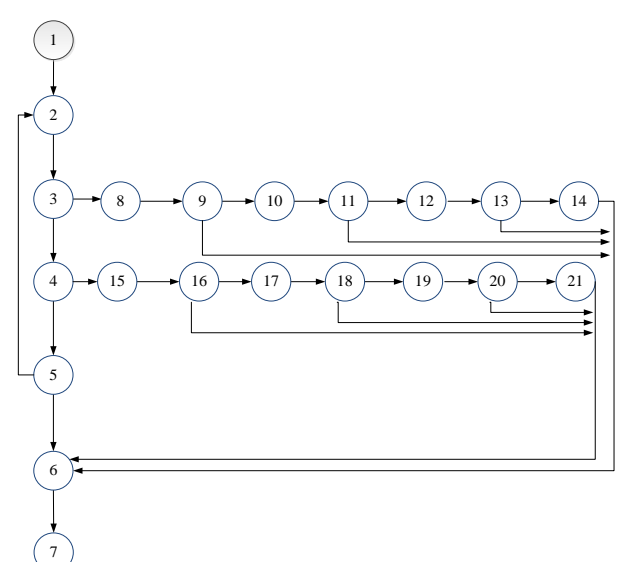

Sumber : Hasil penelitian Gambar 13. Grafik alir scene benda

Kompleksitas sisklomatis (cyclomatic complexity) adalah metrik software yang menyediakan ukuran kuantitatif dari kekompleksan logikal program. Apabila digunakan dalam konteks metode uji coba basis path, nilai yang dihitung untuk cyclomatic complexity menentukan jumlah jalur independen dalam basis set suatu program dan memberi batas atas untuk jumlah uji coba yang harus dikerjakan untuk menjamin bahwa seluruh perintah sekurangkurangnya telah dikerjakan sekali.

Jalur independen adalah jalur yang melintasi atau melalui program dimana sekurangkurangnya terdapat proses perintah yang baru atau kondisi yang baru.Cyclomatic complexity digunakan untuk mencari jumlah path dalam satu flowgraph. Dapat diperoleh dengan perhitungan :

Dimana :

$$
\mathrm{V}(\mathrm{G})=\mathrm{E}-\mathrm{N}+2
$$

$\mathrm{E}=$ Jumlah $e$ dge grafik alir yang ditandakan dengan gambar panah

$\mathrm{N}=$ Jumlah simpul grafik alir yang ditandakan dengan gambar lingkaran

Sehingga kompleksitas siklomatisnya

$$
\mathrm{V}(\mathrm{G})=29-21+2=10
$$

Berikut ini adalah basis set yang dihasilkan dari jalur independent scene benda secara linier:

Path 1: 1-2-3-4-5-6-7

Path 2: 1-2-3-8-9-10-11-12-13-14-6-7

Path 3: 1-2-3-8-9-6-7

Path 4: 1-2-3-8-9-10-11-6-7

Path 5: 1-2-3-8-9-10-11-12-13-6-7

Path 6: 1-2-3-8-9-10-11-12-13-14-6-7

Path 7: 1-2-3-4-15-16-17-18-19-20-21-6-7

Path 8: 1-2-3-4-15-16-6-7

Path 9: 1-2-3-4-15-16-17-18-6-7

Path 10: 1-2-3-4-15-16-17-18-19-20-6-7
Ketika aplikasi dijalankan, maka terlihat bahwa salah satu basis set yang dihasilkan adalah 1-2-3-4-5-6-7 dan terlihat bahwa simpul telah dieksekusi satu kali. Berdasarkan ketentuan tersebut dari segi kelayakan software, sistem telah memenuhi syarat.

b. Black Box Testing

Metode Black Box Testing adalah metode pengujian perangkat lunak dari segi spesifikasi fungsional tanpa menguji desain dan kode program. Dalam penelitian ini diambil scene menu benda sebagai sample black box testing.

\begin{tabular}{|c|c|c|c|}
\hline $\begin{array}{c}I N P U T / E V \\
E N T\end{array}$ & PROSES & $\begin{array}{c}\text { OUTPU } \\
\text { T/ } \\
\text { NEXT } \\
\text { STAGE }\end{array}$ & $\begin{array}{c}\text { Hasil } \\
\text { Penguji } \\
\text { an }\end{array}$ \\
\hline $\begin{array}{l}\text { Klik } \\
\text { Tombol } \\
\text { Lantai 1 }\end{array}$ & $\begin{array}{l}\text { on (release) } \\
\{ \\
\text { nextFrame }() ; \\
\}\end{array}$ & $\begin{array}{l}\text { Tampil } \\
\text { Benda- } \\
\text { benda } \\
\text { lantai } 1\end{array}$ & Sesuai \\
\hline $\begin{array}{l}\text { Klik } \\
\text { Tombol } \\
\text { Lantai } 2\end{array}$ & $\begin{array}{l}\text { on (release) } \\
\{ \\
\text { gotoAndPlay(12); }\end{array}$ & $\begin{array}{l}\text { Tampil } \\
\text { Benda- } \\
\text { benda } \\
\text { lantai } 2\end{array}$ & Sesuai \\
\hline $\begin{array}{l}\text { Klik } \\
\text { Tombol } \\
\text { Home }\end{array}$ & $\begin{array}{l}\text { on (release) }\{ \\
\text { gotoAndPlay("men } \\
\left.\mathrm{u}^{\prime \prime}, 1\right) ; \\
\}\end{array}$ & $\begin{array}{l}\text { Kembali } \\
\text { ke menu } \\
\text { utama }\end{array}$ & Sesuai \\
\hline $\begin{array}{l}\text { Klik } \\
\text { Tombol next }\end{array}$ & $\begin{array}{l}\text { on (release) } \\
\{ \\
\text { nextFrame }() ;\end{array}$ & $\begin{array}{l}\text { Tampil } \\
\text { Gambar } \\
\text { berikutn } \\
\text { ya }\end{array}$ & Sesuai \\
\hline $\begin{array}{l}\text { Klik } \\
\text { Tombol } \\
\text { prev }\end{array}$ & $\begin{array}{l}\text { on (release) } \\
\text { prevFrame(); } \\
\}\end{array}$ & $\begin{array}{l}\text { Tampil } \\
\text { Gambar } \\
\text { sebelum } \\
\text { nya }\end{array}$ & Sesuai \\
\hline
\end{tabular}

Tabel 9. Black box testing scene benda

Sumber : Hasil penelitian

\section{Support}

Berikut ini adalah spesifikasi minimum yang meliputi perangkat keras (hardware) dan perangkat lunak (software) yang mendukung jalanya sistem pada animasi interaktif pengenalan tentang pengenalan benda-benda museum fatahillah yang penulis buat, yaitu:

Tabel 10. Kebutuhan Hardware dan Software

\begin{tabular}{ll}
\hline \multicolumn{1}{c}{ Kebutuhan } & \multicolumn{1}{c}{ Keterangan } \\
\hline Sistem Operasi & $\begin{array}{l}\text { Windows 2000, Windows Xp , 7 dan } \\
\text { sesudahnya }\end{array}$ \\
Proccesor & Pentium Core i3 $2.53 \mathrm{GHz}$ \\
Memory & 2GB \\
Hardisk & $500 \mathrm{~GB}$ \\
Speaker Active & Standard \\
Software & Adobe Flash CS3, Adobe Photoshop \\
\hline Sumber: & CS3 \\
\hline
\end{tabular}

Sumber : Hasil penelitian 


\section{KESIMPULAN}

Melalui animasi interaktif berbasis multimedia ini dapat membantu siswa dan siwi untuk mengenal dan mengoperasikan komputer ataupun laptop. Dengan animasi interaktif benda-benda koleksi museum Fatahillah memudahkan siswa-siswa dalam mengenal benda bersejarah apa saja yang ada di museum Fatahillah animasi interaktif ini dapat membantu siapapun yang hendak ingin mengenal benda-benda sejarah. Disarankan kedepannya animasi interaktif ini tidak hanya dapat beroperasi menggunakan komputer atau laptop berbasis windows, akan tetapi bisa digunakan di operating system android maupun IOS.

\section{REFERENSI}

AS, R., \& Salahuddin, M. (2014). Rekayasa Perangkat Lunak: Terstruktur dan Berorientasi Objek. Bandung: Informatika.

Binanto, I. (2010). Multimedia Digital - Dasar Teori Dan Pengembangannya. Yogyakarta: Andi.

Kartikadarma, E., Rizqa, I., \& Trirosandi, D. (2010). Rancang Bangun Aplikasi E-Museum Sebagai Upaya, 2010(semnasIF), 63-72. Retrieved from lppm.dinus.ac.iddocsprosnnnn.pdf

Ladjamudin, A.-B. Bin. (2006). Rekayasa Perangkat Lunak. Yogyakarta: Graha Ilmu.
Rizky, S. (2011). Konsep Dasar Rekayasa Perangkat Lunak (Software Reengineering). Jakarta: Prestasi Pustaka Publisher.

Sari, V. Y., \& Triyono, R. A. (2013). Pembuatan Video Profil Museum Wayang Indonesia Padepokan Pak Bei Tani Kabupaten Wonogiri. Seruni, $\quad 2 \quad$ No 1 . https://doi.org/http://dx.doi.org/10.0809/seruni .v2i1.682

Susanto, B., \& Budiasa, I. M. (2012). Tantangan Mengelola Museum Sebagai Daya Tarik Wisata. Jurnal Perhotelan, 2.

\section{PROFIL PENULIS}

Ummi Ulfah, Lahir di Jakarta menyelesaikan pendidikan Strata 1 Program Studi Sistem Informasi di STMIK Nusa Mandiri Jakarta tahun 2015.

Syarif Hidayatulloh, Lahir di Jakarta menyelesaikan pendidikan Strata 1 program studi Teknik Informatika di STMIK Nusa Mandiri Jakarta tahun 2014 dan menyelesaikan pendidikan pascasarjana program studi Ilmu Komputer di STMIK Nusa Mandiri Jakarta tahun 2016 